\title{
CORDEN dynamics Stimulator for muscular pain syndromes
}

ÖSSZEFOGLALÁS Bevezetés: Az izomfájdalom szindróma az egyik vezető neurológiai betegség, ami fogyatékosságot okozhat az aktív lakosság körében. A csont- és izomrendszer funkcionális státuszának rehabilitációja, valamint a fizikai és pszichológiai stresszt kezelni lehet fizioterápiával vagy elektroterápiával. Az izomspazmus elkerülése érdekében a gerincoszlop szegmenseit hardware technikával, CORDEN stimulátorral kezeltük, annak érdekében, hogy támogassuk a hipertóniás állapotban lévő mély hátizmok relaxációját.

Cél: a CORDEN stimulátor hatékonyságának tanulmányozása, mint az izomfájdalom szindróma kezelésének egyik eszköze. A beteg testsúlyának figyelembevételével transzverzális irányban akupresszúrás kezelést végeztünk a gerincoszlop ízületein, a facet ízületeken.

Eredmények: A vizsgált alanyok pszichológiai teszteredményei szerint a gerinc korrekciója előtt és után szignifikánsan alacsonyabb neurológiai jelet találtunk a program végére. Az eszköz mechanikus, elektromos és relaxációs hatása javította a gerinc szegmenseinek mobilitását, a közérzetet, enyhítette a fájdalmat, és csökkentette a mentális stresszt.

Következtetés: A kutatás igazolta, hogy a CORDEN cardio stimulátornak pozitív rehabilitációs hatása van a gerincoszlop mentén haladó hátizmok fájdalomszidrómájának kezelésében.

Kulcsszavak: izomfájdalom, CORDEN stimulátor, izomspazmus, az áram relaxációs hatása

ABSTRACT: Introduction: Muscle-pain syndrome is one of the leading neurological disease, and may be cause disability for active population. The rehabilitation of functional state of musculoskeletal organs and considerable physical or psychological stress can be treat by physiotherapy exercises and various types of manual and hardware methods. To eliminate muscle spasm, the hardware offload spinal motion segments using the simulator CORDEN was used, allowing mainly the deep back muscles in a state of hypertonicity relaxation.

Aim: was to study the effectiveness of CORDEN simulator as a means of muscle-pain syndrome management due to the acupressure pressure of the patient's own body weight on the area of transverse processes and facet joints.

Results: According to subjects' psychological testing results before and after the course of spine correction, compared with the control characteristics, significantly lower rates of neuroticism were revealed. The results of the mechanical impact of the device on spinal motion segments in combination with the relaxation effect of the currents on the organism are expressed to improve the well-being, relieve pain and reduce mental stress.

Conclusion: The conducted research has shown that CORDEN cardio simulator is an effective rehabilitative means for muscle-vertebrogenic pain syndrome.

Key words: muscular pain, simulator CORDEN, muscle spasm, relaxing effects of the currents

\section{Introduction}

Muscle pain syndrome (MPS) one of the leading neurological causes of population active part temporary disability (Manvel$o v, 2004 ;$ Yap, 2007). The causes of this muscle-pain syndromes are quite diverse, although several of them are the most typical, for example haed-, trunk-, hip- and knee pains. (Bonica, 1990; Gerwin, 2010 Shevtovs, 2002; Manvelov, 2004; Nizar, 2011; Yap, 2007). Muscle injury, leading to the formation of MPS, is associated primarily with muscle overload. It is believed that MPS most often occurs as a result of constant or repeated muscle low level contractions; maximum and submaximal concentric muscle contractions; repetitive strain of certain muscle groups - postural strain during inactivity (Bonica, 2004; Nizar, 2011; Yap, 2007).
Organism's functional state restoration of persons, subjected to considerable physical stress, as well as persons with hypodynamia may include different types of manual and equipment (apparatus) methods, including different types of massage, surface reflexology methods (Bykov, 2009; Koryukalov, 2012; Shevtzov, 2002; Sumnyi, 2013). However, the problem of finding and applying new effective methods of elimination of over tension, pain syndrome, muscles and the nervous system functional state disorders normalization remains relevant in today's hypodynamia conditions and lack of access to means of recovery. The aim of the research was to study the effectiveness of CORDEN simulator as a means of muscle-pain syndrome management due to the acupressure pressure of the patient's own body weight on the area of transverse processes and facet joints.

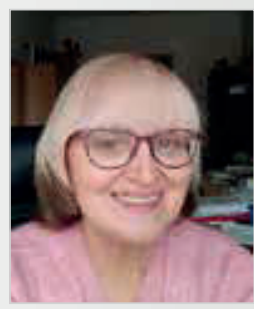

Author: NADEZHDA PETRUSHKINA Workplace: Ural State University of Physical Culture Department of Physiology Scientific activity: Technologies and management of physical recreation for people in different ages

E-mail:25ppnn@mail.ru

Head of the Department of Physiology in Ural State University of Physical Culture. Scientific activities are physiology, sports physiology, sports medicine, age physiology, ecology, radiobiology. Hobby: traveling, gardening plants. fitness, swimming

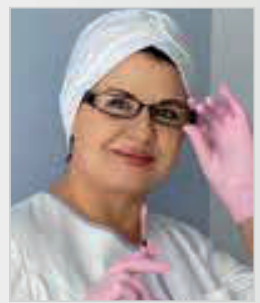

Author: OLGA KOLOMIEC E-mail:kolomiec_0@mail.ru Associate professor in Department of Sports Medicine and Physical Rehabilitation. Candidate of biological sciences have many articles and lecture in several countries. Plays a role in manging international relations. Hobby: nutritional science

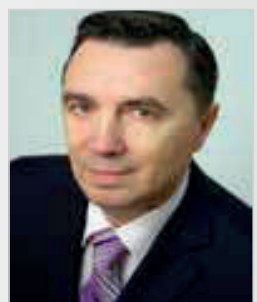

Author: EVGENII BYKOV

E-mail: bev58@yavdex.ru Doctor of medidal sciences. Main scientific interests: sport cardiology, rehabilitation, health promotion for people in different ages by physical culture. Author of more than 300 scientific articles or monography, eg.: examination of human reservs and adaptaion in stress situation. Restitution and rehabilitation in sport. Chess master candidate.

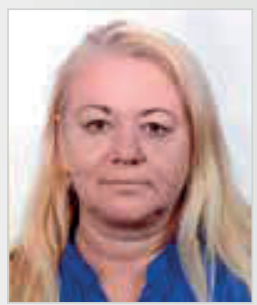

Correspondent author: JUDIT PLACHY E-mail: plachy.judit@gmail.com Assistant professor in University of Miskolc Faculty of Health Care. Main scientific interests: physiotherapy, health promotion, rehabilitation, physical recreation mainly for older adults. Manage recreation programmes by different sport activities: Pilates and several aerobics methods. Hobby: doing different training exercises, managing recreation programmes. 


\section{Methods}

The research was conducted in accordance with generally accepted requirements (Bykov et. al, 2019). The sample was chosen with varying degrees of muscle pain. 19 patients were examined from the Physiotherapy department of the Chelyabinsk regional clinical hospital. Their age was between 45 - $53(M=49.5 \pm 3.45 S D)$. Patients were selected for the correction group to participate in the study after preliminary examination and obtaining informed consent for the study.

Previously, doctors of the department were acquainted with the CORDEN simulator, the applied methodology set out by the manufacturer in the instructions. CORDEN is an innovative exercise machine, which design allows treat the paravertebral muscles area and relax them (Denicsenko - Bykov, 2019). Bioelectric currents are also modulated in CORDEN, allowing changing the functional state of the nervous system (NS) in relaxation direction, and they have an anti-stress effect. The procedure for spine osteopathic correction and nervous system state was that CORDEN was put under the vertebral-motor segments in the cervical, thoracic and lumbar spine of a patient in the lying position. After 30 minutes of correction, the patient performed several traction and mobilization physical exercises (Figure 1.).

Treatment effectiveness was assessed by the pain syndrome dynamics, psycho-emotional status and motor tests performance. Patients evaluated pain in the cervical and lumbar spine twice during the day (from 6 to 18 hours and from 18 to 6 hours).

Quantitative pain assessment was performed by a visual analogue scale (VAS) (Bonica, 1990): 1 point - slight discomfort, 10 points - acute pain that requires strong painkillers. To assess the psychofunctional status of the patients' definition of neuroticism - emotional instability at G. A. Eysenk and determination of neuro-psychic tension state (NPT) by T. A. Nemchinov were used (Aizek, 1972).
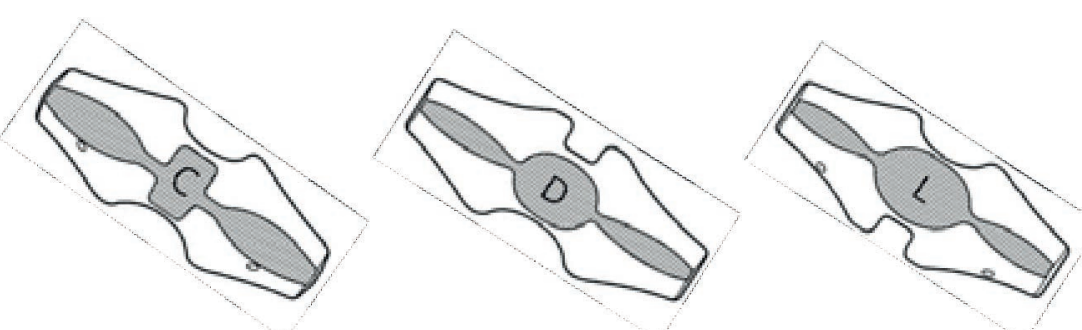

Petrushkina - figures

Figure 1.: Corden simulator (C-cervicalis; D-dorsalis; L-lumbaris)

\begin{tabular}{|c|c|c|c|c|c|c|}
\hline \multirow{3}{*}{$\begin{array}{l}\text { Pain localization } \\
\text { Observation period }\end{array}$} & \multicolumn{6}{|c|}{$\begin{array}{l}\text { Average pain values }(\mathrm{M}) \text {, error in mean }(\mathrm{m}) \text {, quadratic } \\
\text { fluctuations }(\sigma)\end{array}$} \\
\hline & \multicolumn{3}{|c|}{ From 6 till 18 hours } & \multicolumn{3}{|c|}{ From 18 till 6 hours } \\
\hline & $\mathrm{M}$ & $\mathrm{m}$ & $\sigma$ & M & $\mathrm{m}$ & $\sigma$ \\
\hline \multicolumn{7}{|l|}{$\begin{array}{l}\begin{array}{l}\text { Pains in } \\
\text { section }\end{array} \\
\end{array}$} \\
\hline Before the experiment & 6.9 & 0.19 & 0.81 & 6.8 & 0.13 & 0.54 \\
\hline After the experiment & 3.1 & 0.26 & 0.52 & 2.5 & 0.19 & 0.81 \\
\hline \multirow[t]{2}{*}{ Student's criterion ( $t$ ) } & \multicolumn{3}{|c|}{$11.90(\mathrm{p}<0.05)$} & \multicolumn{3}{|c|}{$9.59(\mathrm{p}<0.05)$} \\
\hline & \multicolumn{6}{|c|}{$\underline{\text { Pain in lumbar spine }}$} \\
\hline \multicolumn{7}{|l|}{ Pain in lumbar spine } \\
\hline Before the experiment & 5.2 & 0.32 & 1.36 & 6.7 & 0.13 & 0.54 \\
\hline After the experiment & 1.9 & 0.13 & 0.54 & 2.0 & 0.12 & 0.56 \\
\hline Student's criterion ( $t$ ) & \multicolumn{3}{|c|}{$18.67(\mathrm{p}<0.05)$} & \multicolumn{3}{|c|}{$26.01(\mathrm{p}<0.05)$} \\
\hline
\end{tabular}

Table 1.: Pain evaluation dynamics in different sections of locomotor apparatus before and after the experiment

\begin{tabular}{|c|c|c|c|c|c|c|c|}
\hline \multirow{3}{*}{ Values } & \multicolumn{7}{|c|}{$\begin{array}{l}\text { Observation period, mid-values }(\mathrm{M}) \text {, error in mean }(\mathrm{m}) \text {, } \\
\text { quadratic fluctuations }(\sigma) \text {, Student's criterion }(\mathrm{t})\end{array}$} \\
\hline & \multicolumn{3}{|c|}{$\begin{array}{l}\text { before the correction } \\
\text { course }\end{array}$} & \multicolumn{3}{|c|}{$\begin{array}{l}\text { after the correction } \\
\text { course }\end{array}$} & \multirow[t]{2}{*}{$\mathrm{t}$} \\
\hline & $\mathrm{M}$ & $\mathrm{m}$ & $\sigma$ & $\mathrm{M}$ & $\mathrm{m}$ & $\sigma$ & \\
\hline $\begin{array}{l}\text { Neuro-psychic } \\
\text { tension state } \\
\text { (NPS) }\end{array}$ & 48.7 & 0.57 & 2.43 & 42.6 & 0.57 & 2.45 & $\begin{array}{l}7.50 \\
\mathrm{p}<0.05)\end{array}$ \\
\hline Neuroticism & 14.5 & 0.32 & 1.36 & 9.6 & 0.26 & 1.08 & $\begin{array}{l}11.76 \\
\mathrm{p}<0.05)\end{array}$ \\
\hline
\end{tabular}

Table 2.: Neuro-psychological status dynamics before and after the correction course, using spine simulator CORDEN

\begin{tabular}{|l|l|l|l|l|l|l|l|}
\hline \multirow{2}{*}{ Tests* } & \multicolumn{6}{|l|}{$\begin{array}{l}\text { Observation period, mid-values (M), error in mean (m), quadratic } \\
\text { fluctuations }(\sigma), \text { Student's criterion }(\mathrm{t})\end{array}$} \\
\cline { 2 - 8 } & \multicolumn{6}{|l|}{ before the correction course } & \multicolumn{2}{l|}{ after the correction course } & \multirow{2}{*}{$\mathrm{t}$} \\
\cline { 2 - 8 } & $\mathrm{M}$ & $\mathrm{m}$ & $\sigma$ & $\mathrm{M}$ & $\mathrm{m}$ & $\sigma$ & \\
\hline Test 1 & 20 & 1.28 & 5.42 & 42 & 1.88 & 3.96 & $\begin{array}{l}7.40 \\
(\mathrm{p}<0.05)\end{array}$ \\
\hline Test 2 & 0.5 & 0.06 & 0.24 & 0.8 & 0.06 & 0.27 & $\begin{array}{l}3.49 \\
(\mathrm{p}<0.05)\end{array}$ \\
\hline
\end{tabular}

Table 3.: Tests dynamics, showing changes in lumbar spine mobility before and after the course of correction by spine simulator CORDEN

* Test 1 - lifting the trunk, hands elongated forward, on the floor, not lifting legs (angle between the floor and the hand line in degrees); Test 2 - putting arms with a stick behind a head (wide grip) $(150 \mathrm{~cm})$ in standing position ( 1 - fulfilled, 0 - not fulfilled) 
Two dynamics motor tests results was considered: Test 1 - lifting the trunk, hands elongated forward on the floor, not lifting legs (angle between the floor and the hand line in degrees); Test 2 - putting arms with a stick behind a head (wide grip) $(150 \mathrm{~cm})$ in standing position (1fulfilled, $o$ - not fulfilled).

To evaluate the research result, the mean values of the test results in dynamics (before and after the experiment), mean errors and quadratic deviations were calculated. Reliability of differences was determined by Student's criterion (95\% significance level) (Bykov et. al, 2019).

\section{Results}

The assessment of the pain syndrome severity showed a significant decrease in the severity of pain after the correction course (Table 1).

According to patients' psychological testing results before and after the course of spine correction, compared with the control characteristics, significantly lower rates of neuroticism were revealed (Table 2).

The obtained data, probably, show expressed emotional stability, contributing to the preservation of organized behavior, situational purposefulness in normal and stressful situations, characterized by «good» adaptation development in these persons, after the correction course.

Neuroticism characteristics before the correction course in- dicate these persons' instability in stressful situations and «bad» adaptation.

Neuro-psychic stress (NPS) characteristics were also significantly lower after the course of spine correction on the CORDEN simulator (Table 2). At the same time, the patients after the course of correction (according to the questionnaire) did not actually make any complaints about physical and mental discomfort and overwhelmingly preferred the points of the questionnaire, which indicate the absence of their previous discomfort from the somatic and mental state.

The subjects noted a decrease in stiffness in the cervical, thoracic and lumbar spine, improved mobility in the upper and lower limbs, increased efficiency and motor activity. It is proved by improving test execution. (Table 3).

Besides, during the questioning all patients noted sleep normalization, cardiac activity, genitourinary system and appetite normalization. It was noted the disappearance of headaches, reducing tension in the back and epigastric region contributed to posture improvement.

It is known that the source of back pain is a volitional impulse coming from damaged spinal tissues and unrelated structures such as: joints, internal organs, ligaments and muscles (paravertebral and extravertebral). The source of pain in the spinal-motion segment can be ligaments and muscles, processes' periosteum, protruding disc and sy- novial membranes of intervertebral joints. All nociceptive impulses, regardless of their source, penetrate the central nervous system. At the same time, pain impulses activate the alpha and beta motor neurons of the anterior horns of the spinal cord. Anterior motor neurons activation leads to hypertonus of the muscles innervated by this spinal cord segment.

CORDEN is an innovative simulator allowing to dive into the area of paravertebral muscles and relax them. In addition, CORDEN modulates bioelectric currents, allowing to change the nervous system functional state to relaxation, i.e. they have an anti-stress effect. An important point is performance of traction and mobilization physical exercises by the patient after 30 minutes of correction.

\section{Conclusion.}

The conducted research has shown that CORDEN cardio simulator is an effective rehabilitative means for muscle-vertebrogenic pain syndrome. It can be proved by a decrease in pain, a decrease in neuropsychic tension and neuroticism level, sleep normalization, increased performance and motor activity.

So, CORDEN simulator is an effective remedy for muscular pain syndrome of vertebrogenic nature management, an effective tool for enhancing the adaptive mechanis$\mathrm{ms}$ by reducing mental stress and neuroticism.

\section{References}

Aizenk, G.Yu. (1972): Test your abilities. in: G.Yu. Aizenk. (ed.), Mir (Mnp), 1-174 p.

Bonica, J.J. (1990): General considerations of pain in the chest in. J. J. Bonica (ed.), The Management of pain. Lea \&Febiger, Philadelphia, 1-959 $p$.

Bykov E.B. - Petrushkina N.P. - Kolomiec O.I., Szimonova, N.A. (2019): Методологические подходы при организации научных исследований в сфере физической культуры и спорта/ Педагогико-пси хологические и медико-биологические проблемы физической культуры и спорта. Том 14, 176-184 p. DOI 10.14526/2070-4798-2019-14-1-176-184 http:// journalsport.ru/images/vipuski/14-1/24.pdf

Bykov, E.V. (2009): The effect of superficial acupuncture (redox treatment) on sportsmen's psychophysiological state. (in) E. V. Bykov, T. V. Potapova, R. F. Gil'metdinov, A. V. Chipyshev (ed). Issues of balneology, physiotherapy and therapeutic physical culture, 1-11 p.

Denicsnko, V.C. - Bykov E.V. (2019): Физиологические эффекты применения тренажера corden при коррекции состояния лиц с дорсопатиями / В сборнике: Проблемы подготовки научных и научно-педагогических кадров: опыт и перспективы // Сборник научных трудов молодых ученых, посвященный Дню российской науки, 53-60 p. Gerwin, R. (2010): Myofascial pain syndrome: here we are, where must we go?, Journal of Musculoskeletal Pain, 18./ 329-347 p.

Koryukalov, Yu.I. (2012): Innovative apparatus for spine correction./ Medicine: nowadays challenges :Materials of the international virtual scientific conference. Chelyabinsk, June 2012, 30-32 p.

Manvelov L.S. (2004): Vertebrogenic pain syndromes. L. S. Manvelov (ed) Atmpsphere. Nerve diseases, 3/42-44 p.

Meyers, W.C. (2000): Management of severe lower abdominal or inguinal pain in high-performance athletes. PAIN (Performing Athletes with Abdominal or inguinal Neuro-muscular Pain Study Group), American Journal of Sports Medicine, 28/2-8 p.

Nizar, A.J. (2011): Myofascial Pain Syndrome in Chronic Back Pain Patients. Korean Journal of Pain,
24/2.100-104 p.

Shevtzov A.V., Formin A.N. (2002): Technology of painful myofascial syndrome removal by means of the individual disfunctions corrector in a spinal column, Family health - XXI century: Materials of IV International scientific conference, 1-3 May, Dubai United Arab Emirates. - Perm', Dubai, 166-167 p.

Sumnyi N.A. (2013): Rehabilitation of patients with cervical degenerative disc disease with vertebral-motor segments instability syndrome with the use of laser therapy and its effect on the activity of lipids peroxidation and antioxidant systems. Allergology and immunology, 14/1-50 p.

Szazonpova E.A. - Denicsenko V.C. - Bykov E.V. (2018): Влияние тренажера corden на отдельные системы организма / В сборнике: Актуальные вопросы реабилитации, лечебной и адаптивной физической культуры и спортивной медицины // Материалы Всероссийской научно-практической конференции, 296-302 p.

Yap, E.C. (2007): Myofascial pain-an overview. Ann. Acad. Med. Singapore, 36/43-48 p. 